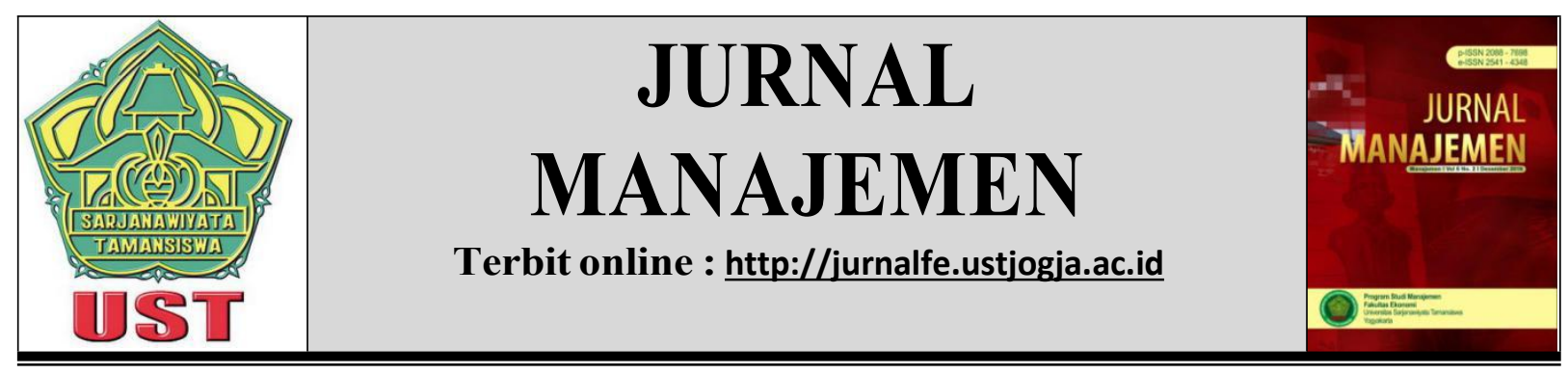

\title{
ANALISIS BIAYA PRODUKSI UNTUK PRODUK BOTOL PLASTIK PADA INDUSTRI MANUFAKTUR
}

\author{
Yevita Nursyanti \\ Program Studi Manajemen Industri Elektronika, Politeknik APP Jakarta \\ Email: yevita.nursyanti@gmail.com
}

\begin{tabular}{ll}
\hline Informasi Naskah & \multicolumn{1}{c}{ Abstrak } \\
\hline $\begin{array}{l}\text { Diterima: 22 Agustus } \\
\mathbf{2 0 1 9}\end{array}$ & $\begin{array}{l}\text { Cost of Goods Sold (COGS) is a method for calculating all direct and } \\
\text { Revisi: } 2 \text { Desember } 2019\end{array}$ \\
Terbit: 18 Desember & statements on sales results. This study aims to minimize costs when \\
2019 & going to carry out production process activities. This analysis model \\
Kata Kunci: Full & uses the full costing method by calculating all costs incurred in the \\
Costing, production cost & takes into account all production costs, such as direct raw material \\
& costs, direct labor, variable overhead costs and fixed overhead costs. By \\
& using the cost of goods sold calculation method both the full costing \\
& method and variable costing can help management determine the selling \\
& price of the product in the sales process. The result of total production \\
& cost calculation using the full costing method is Rp 1,889,682,559 with \\
& total sales of 15,000,000 units multiplied by the selling price per bottle \\
& of Rp 150.00 then the selling price of Rp 2,250,000,000.00. The profit \\
& after tax was IDR 249,084,826.69 obtained from the sale of plastic \\
& bottles.
\end{tabular}

\section{PENDAHULUAN}

Didalam suatu perusahaan, pada saat memberikan suatu keputusan mengenai penetapan harga produk merupakan hal yang sangatlah penting dan tidaklah mudah untuk dilakukan. Penetapan harga harus ditetapkan secara tepat, cermat, dan akurat. Hal ini dilakukan agar suatu perusahaan dapat bersaing dengan perusahaan-perusahaan lain yang memproduksi produk sejenis dalam kurun waktu yang relatif lama. Akuntansi biaya mempunyai tiga tujuan pokok yaitu: Mulyadi (2012:7-8)

1) Penentuan Harga Pokok Produksi;

2) Pengendalian Biaya ;

3) Pengambilan Keputusan Khusus. 
Akuntansi biaya merupakan bidang khusus akuntansi yang berkaitan terutama dengan akumulasi dan analisis biaya untuk penentuan harga pokok produk yang dihasilkan, serta untuk membantu manajemen dalam perencanaan, pengendalian dan pengambilan keputusan. Firdaus dan Warsilah (2009:17). Biaya atau Cost adalah kas atau ekuivalen kas yang dikorbankan untuk membeli barang atau jasa yang diharapkan akan memberikan manfaat bagi perusahaan saat sekarang atau untuk periode mendatang. Krismiaji \& Aryani (2011:17)

Dijelaskan juga didalam buku lainnya bahwa berdasarkan penentuan harga pokok produk yang benar dari suatu produk akan dapat mengurangi ketidakpastian dalam penentuan harga jua. Dalam penentuan harga pokok produk harus diperhatikan unsur-unsur biaya apa saja yang masuk dalam harga pokok produk dan mengalokasikan unsur-unsur biaya tersebut secara tepat sehingga dapat menggambarkan pengorbanan sumber ekonomi yang sesungguhnya. Andre Henri Slat, (2013)

Sebagai salah satu produsen kemasan plastik industri memberikan inovasi, presisi, fitur unik dan teknologi maju untuk menyediakan produk yang sesuai dengan harapan klien. Fasilitas in-house mereka memungkinkan untuk merancang dan memproduksi produk dengan kualitas, hemat biaya serta solusi berkelanjutan terhadap lingkungan. Produk dibagi menjadi beberapa segmen termasuk kosmetika, farmasi, makanan \& minuman, bahan peledak, peralatan rumah tangga dan produk industri. Mesin-mesin tersebut mampu menghasilkan berbagai macam produk dan layanan dengan menggunakan injeksi dan blow molding, Cap atau Lid sebagai fasilitas pembuatan cetakan mereka. Industri memproduksi produk yang terbuat dari bahan resin seperti Polycarbonate (PC), Polyethylene (PE), Polipropilena (PP), Polivhynilchloride (PVC), Polistirena (PS), Acrylonitrile butadiene stirena (ABS) dan Polyethylene Terephthalate (PETE). Orang orang berpengalaman merekasiap memberikan bantuan dan rekomendasi untuk menyesuaikan desain sesuai dengan dimensi, dan fungsional yang terbaik.

Harga pokok produksi wajib dilakukan untuk menentukan harga jual dan dalam menentukan harga jual terlebih dahulu harus diketahui harga pokok dari pembuatan produknya dan berapa biaya produksi yang dikeluarkan, sehingga produk tersebut dapat bersaing dengan produk lain dipasaran.

\section{KAJIAN PUSTAKA}

Penentuan harga pokok adalah bagaimana memperhitungkan biaya kepada suatu produk atau pesanan atau jasa, yang dapat dilakukan dengan cara memasukkan seluruh biaya produksi atau hanya memasukkan unsur biaya produksi variabel saja. Bustami dan Nurlela (2008 : 40). Metode penentuan harga pokok produksi dengan metode full costing membebankan seluruh biaya produksi, yang terdiri dari biaya bahan baku, biaya tenaga kerja langsung, biaya overhead pabrik, baik yang berperilaku tetap maupun variabel kepada produk.

Hal ini karena dengan menggunakan metode full costing semua biaya dirinci secara jelas, baik itu biaya bahan baku, tenaga kerja langsung, dan biaya overhead pabrik sedangkan pada perhitungan harga pokok produksi dengan perhitungan yang digunakan perusahaan harga 
pokok produksi yang dihasilkan lebih kecil karena perusahaan tidak memasukkan biaya overhead pabrik secara rinci ke dalam biaya produksinya serta dengan metode full costing mampu menyajikan laporan keuangan sesuai dengan prinsip Akuntansi Indonesia yang menghendaki kewajaran laporan keuangan kepada pihak ekstenal perusahaan. Prinsip Akuntansi Indonesia mengikuti konsep penentuan harga pokok penuh karena harga pokok berarti jumlah pengeluaran langsung atau tidak langsung untuk menghasilkan barang atau jasa didalam kondisi dan tempat dimana barang atau jasa tersebut di jual, dan juga metode full costing memasukkan seluruh elemen biaya dalam perhitungan harga pokok produk baik biaya variabel maupun biaya tetap atau period cost. Mulyadi (2005:17)

JIka dalam memperhitungkan harga pokok produksi terdapat kesalahan, hal tersebut akan berdampak dalam proses penentuan harga jual pada suatu perusahaan sehingga proses penentuan harga jual menjadi terlalu tinggi atau terlalu rendah serta juga menimbulkan kesalahan dalam penentuan nilai persedian produk jadi (finish good) dan produk dalam proses (WIP), Maka jika ada kesalahan dalam penentuan harga jual, perusahaan akan rugi atau kehilangan pelanggan karena harga jual yang ditentukan terlalu rendah maupun terlalu tinggi.

Harga jual yang terlalu tinggi dapat mengakibatkan produk yang ditawarkan perusahaan akan sulit bersaing dengan produk sejenis yang ada di pasar, sebaliknya jika harga jual produk terlalu rendah akan mangakibatkan laba yang diperoleh perusahaan rendah pula. Hal tersebut dapat diatasi dengan penentuan harga pokok produksi dan menetukan harga jual yang tepat. Harga pokok merupakan faktor terpenting dalam pertimbangan untuk menentukan harga jual suatu produk yang nantinya diharapkan akan mendatangkan laba bagi perusahaan. Stanton

\section{(1993:316)}

Dalam hal ini, sebagian para pengusaha sudah menyadarinya bahwa potensi yang ada dalam pasar sangat kecil, karena produk-produk sejenis yang diproduksi oleh perusahaan lain berupa botol plastic ini sudah cukup banyak. Untuk mengatasi hal itu perusahan dituntut untuk memberikan harga atau nilai jual dari produk tersebut dengan sangat tepat dan wajar. Dengan mengunakan metode full costing tersebut perusahaan berharap dapat memberikan harga jual yang tepat dengan memperhitungkan mulai dari harga pokok produksi hingga harga pokok penjualan.

Full Costing merupakan metode penentuan harga pokok produksi yang memperhitungkan semua unsur biaya produksi, yang terdiri dari biaya bahan baku, biaya tenaga kerja langsung, dan biaya overhead pabrik, baik variabel maupun tetap ditambah dengan biaya non produksi (biaya pemasaran, biaya administrasi dan umum). Mulyadi (2012:18). Harga pokok produksi adalah total harga pokok produk yang diselesaikan selama periode berjalan. Hansen danMowen (2009). Sedangkan sejumlah nilai aktiva (asset), tetapi apabila selama tahun berjalan aktiva tersebut dimanfaatkan untuk membantu memperoleh penghasilan, aktiva tersebut harus dikonversikan ke beban (expense). Witjaksono (2006). Maka dalam hal ini permasalahan yang diangkat pada saat observasi pada Pt Tunggal Jaya Plastik Industri yaitu perhitungan biaya produksi yang dilakukan dengan metode full costing pada Pt Tunggal Jaya Plastik Industri ialah dengan menghitung seluruh biaya yang dikeluarkan dalam proses 
produksi botol plastik. Biaya yang dihitung oleh pabrik ini belum mencakup semua biaya yang dikeluarkan.

\section{METODE PENELITIAN}

Dalam melakukan penyelesaian penelitian ini menggunakan perhitungan harga pokok penjualan pada industri manufatktur dengan metode full costing atau kalkulasi biaya penuh dimana metode full costing ini memperhitungkan semua biaya produksi, seperti biaya bahan baku langsung, tenaga kerja langsung, biaya overhead variable dan biaya overhead tetap. Dengan menggunakan metode perhitungan harga pokok penjualan baik metode full costing dapat membantu manajemen dalam menentukan harga jual produk. Pada metode full costing biaya overhead pabrik baik yang variable maupun tetap, dibebankan kepada produk atas dasar tarif yang ditentukan di muka pada kapasitas normal atau atas dasar biaya yang sesungguhnya Selisih BOP akan timbul apabila BOP yang dibebankan berbeda dengan BOP yang sesungguhnya terjadi. Dalam laporan laba rugi dalam metode full costing laporan laba rugi tersebut menyajikan biaya-biaya menurut hubungan biaya dengan fungsi pokok dalam perusahaan manufaktur, yaitu fungsi produksi, fungsi pemasaran dan fungsi administrasi dan umum. Dalam melakukan pengumpulan data untuk penelitian ini, teknik yang digunakan berdasarkan jenis data adalah sebagai berikut:

1. Data primer

Teknik pengumpulan data primer yang dilakukan adalah sebagai berikut

a. Observasi : obeservasi dilakukan secara langsung pada industri manufaktur dan melakukan pengamatan terhadap proses bisnis di industri, mulai dari proses produksi, penyimpanan, sampai pendistribusian barang.

b. Komunikasi : komunikasi dilakukan dengan cara wawancara secara langsung kepada pihak perusahaan terkait dengan aktivitas produksi, keuangan, transportasi dan penyimpanan

2. Data sekunder

Teknik pengumpulan data sekunder yang didapatkan pada industri manufaktur . Data yang diperoleh diantaranya adalah profil perusahaan, struktur organisasi, data biaya dan keuangan perusahaan

\section{HASIL DAN PEMBAHASAN}

Pada saat pelaksanaan observasi didapatkan rincian biaya bahan baku langsung pada industri manufaktur, berikut adalah tabel biaya untuk bahan baku langsung untuk produk botol plastik: 
Tabel 1 Biaya Bahan Baku Langsung

\begin{tabular}{rlr}
\hline \multicolumn{3}{l}{ 1. Biaya Bahan Baku Langsung } \\
\hline & Harga Biji Plastik/kg & Rp. 13,000 \\
Biji & $1 \mathrm{Kg}$ & Berat Biji Plastik / \\
Plastik & Botol & 6g \\
& $1 \mathrm{Kg}->$ botol ? & 166 Botol \\
& Harga pewarna / Bulan Rp. 1.174.698.795.18 \\
\hline
\end{tabular}

Sumber: Data diolah

Industri memiliki persediaan awal bahan baku biji plastik sebanyak $50 \mathrm{~kg}$ sebagai safety stock (cadangan pengaman) di dalam gudang. Harga $1 \mathrm{~kg}$ atau 1000 gr biji plastik (HDPE) yang dibeli dari supplier adalah $\mathrm{Rp}$ 13.000. Dalam menghasilkan satu botol plastik membutuhkan 6 gr biji plastik sehingga dalam $1 \mathrm{~kg}$ biji plastik akan menghasilkan 166 unit botol plastik. Sehingga industri memiliki nilai barang safety stock di dalam gudang sebesar Rp. 650.000. Untuk tenaga kerja langsung industri menghitung berdasarkan Upah Minimum Kabupaten dengan total gaji perorang selama satu bulannya sebesar Rp 3.204.551/bulan. Satu mesi produksi menghasilkan 100.000 unit botol plastik, industri memiliki delapan mesin dimana enam mesin merupakan mesin yang khusus untuk membuat botol dan dua mesin lainnya digunakan untuk memproduksi barang lainnya. Sehingga dalam satu hari, industri dapat menghasilkan 600.000 unit botol. Dalam satu bulan industri dapat menghasilkan 15.000.000 botol. Sehingga total pengeluaran untuk membeli biji plastik adalah sebesar Rp. 1.174.698.795.

Tabel 2 Biaya Tenaga Kerja Langsung

\begin{tabular}{cccr}
\hline \multicolumn{4}{c}{ 2.Biaya Tenaga Kerja Langsung } \\
\hline Gaji & Gaji & $\mathrm{Rp}$ & 3.204 .551 \\
Operator & Jumlah Orang & & 48 \\
Mesin & Total & $\mathrm{Rp}$ & 153.818 .448 \\
\hline
\end{tabular}

Sumber: Data diolah

Industri manufaktur memiliki tenaga kerja langsung sebanyak 48 orang dengan gaji perbulan sebesar Rp. 3.204.551 sehingga dalam satu bulan perusahaan mengeluarkan biaya untuk membayar gaji karyawan sebesar Rp. 153.818.448, selain itu perusahaan masih terus mengeluarkan untuk biaya overhead. Berikut biaya overhead pabrik yang meliputi :

1. Bahan penolong

a. Pewarna

Digunakan untuk pewarnaan pada botol. Satu kilogram pewarna seharga Rp. 9000 dengan kebutuhan pewarna dalam satu botol sebanyak $3 \mathrm{gr}$. Sehingga dalam $1 \mathrm{~kg}$ pewarna menghasilkan 500 botol. Untuk memenuhi 15.000 .000 produksi botol perusahaan mengeluarkan uang untuk membeli pewarna sebesar Rp 270.000.000. 
b. Kardus

Digunakan untuk mengemas botol yang sudah jadi dan siap dikirim ke konsumen. Dalam satu kardusnya, berisi 550 botol dengan pengiriman setiap harinya. Satu hari, industri menghasilkan 600.000 botol (dengan 25 hari kerja dalam sebulan). Sehingga kardus yang dibutuhkan kurang lebih 1.091 kardus. Satu buah kardus dihargai oleh supplier sebesar Rp 2.400. Total biaya yang dikeluarkan untuk pembelian kardus adalah sebesar $\mathrm{Rp}$ 65.460.000.

c. Label

Digunakan untuk informasi tertulis yang ditempel pada kardus pengemasan botol. Dengan kebutuhan kardus sebanyak kurang lebih 1.091 pcs. Harga label per pcs adalah sebesar Rp 300. Sehingga total pengeluaran untuk pembelian label adalah sebesar Rp8.182.500 (untuk periode 25 hari/bulan).

2. Biaya air

Biaya air yang dikeluarkan adalah Rp 350.000 untuk pemakaian selama satu bulan (periode 25 hari kerja).

3. Biaya Listrik

Biaya listrik terdiri dari 2,yaitu listrik kantor dan listrik pabrik. Dalam satu bulannya, listrik kantor memerlukan Rp 3.000.000. Dan listrik pabrik sebesar Rp 150.000.000.

4. Biaya Telepon

Biaya telepon adalah sebesar Rp 3.000.000. Biaya listrik terdiri dari 2,yaitu listrik kantor dan listrik pabrik. Dalam satu bulannya, listrik kantor memerlukan $\mathrm{Rp}$ 3.000.000. Dan listrik pabrik sebesar Rp 150.000.000

5. Gaji Tenaga Kerja Tidak Langsung

a. Gaji Satpam

Industri memiliki 2 orang satpam untuk satu shiftnya. Dalam satu hari kerja, industri menetapkan 3 shift. Sehingga total satpam yang dimiliki adalah 6 orang. Satu orang satpam digaji berdasarkan UMR sebesar Rp 3.204.551. Total pengeluaran untuk menggaji satpam adalah sebesar Rp 19.227.306.

b. Gaji Resepsionis

Industri hanya memiliki 1 orang resepsionis dengan gaji Rp 3.204.551.

c. Gaji QC

Terdapat 3 orang QC dalam satu shiftnya dan total shift dalam sehari adalah 3 . Maka jumlah QC yang dimiliki adalah 9 orang. Dengan gaji per orangnya sebesar Rp 3.204.551, maka total gaji QC seluruhnya adalah sebesar Rp 28.840.959.

d. Gaji QC Supervisor

Gaji QC Supervisor adalah sebesar Rp 4.500.000 untuk satu orangnya. Industri memiliki 2 orang QC supervisor sehingga total gaji sebesar Rp 9.000.000. Total dari bahan overhead pabrik adalah senilai Rp564.165.316.

Berdasarkan identifikasi biaya pada pembahasan sebelumnya maka dapa dihasilkan perhitungan Laporan Harga Pokok Produksi pada Tabel 4. Selanjutnya dalam untuk perhitungan Harga Pokok Penjualan dengan cara menghitung biaya produksi dengan cara 
menjumlahkan biaya tenaga kerja langsung, biaya bahan baku langsung digunakan dan biaya overhead pabrik. Sehingga diperoleh hasil Rp 1.836.972.619,42. Industri manufaktur menggunakan sistem make to order atau tidak tidak membuat untuk persediaan maka inudstri tidak memiliki barang work in process.

Tabel 3 Perhitungan HPP

\begin{tabular}{|c|c|c|}
\hline \multicolumn{3}{|c|}{$\begin{array}{l}\text { LAPORAN HARGA POKOK PENJUALAN } \\
\text { Periode Agustus } 2017\end{array}$} \\
\hline Persediaan Bahan Awal & & $\begin{array}{c}\mathrm{Rp} \\
650,000\end{array}$ \\
\hline $\begin{array}{l}\text { Pembelian Bahan Awal } \\
\text { Ongkos Angkut Pembelian }\end{array}$ & $\begin{array}{r}\text { Rp. } \\
1.174 .698 .795,18 \\
\text { Rp.2.500.000,00 } \\
\end{array}$ & \\
\hline Retur dan Potongan Pembelian & $\begin{array}{r}\mathrm{Rp} . \\
1.177 .198 .795,18 \\
\text { Rp. 58.859.939,76 (-) }\end{array}$ & \\
\hline Pembelian Bersih & & $\begin{array}{c}\text { Rp. } \\
1.118 .338 .855,42 \\
\end{array}$ \\
\hline $\begin{array}{l}\text { Bahan Teersedia Untuk Dipakai } \\
\text { Persediaan Bahan Akhir }\end{array}$ & & $\begin{array}{c}\text { Rp. } \\
1.118 .988 .855,42\end{array}$ \\
\hline $\begin{array}{l}\text { Bahan Baku Langsung Digunakan } \\
\text { Tenaga Kerja Langsung } \\
\text { Biaya Overhead Pabrik }\end{array}$ & & $\begin{array}{c}\text { Rp. } \\
1.118 .988 .855,42 \\
\text { Rp. } 153.818 .448,00\end{array}$ \\
\hline $\begin{array}{l}\text { Bahan Penolong } \\
\text { Tenaga Kerja Tidak Langsung } \\
\text { Biaya Listrik Office } \\
\text { Biaya Listrik Pabrik } \\
\text { Biaya Air } \\
\text { Biaya Telepon } \\
\text { Biaya Overhead Lainnya }\end{array}$ & $\begin{array}{r}\text { Rp.347.542.500,00 } \\
\text { RP. } 60.272 .816,00 \\
\text { Rp.3.000.0000,00 } \\
\text { Rp.150.000.000,00 } \\
\text { Rp. } 350.0000,00 \\
\text { Rp. } 3 \cdot 000.000,00 \\
-(+)\end{array}$ & \\
\hline Total BOP & & Rp. $564 \cdot 165.316,00$ \\
\hline $\begin{array}{l}\text { Biaya Produksi } \\
\text { Persediaan Produk Dalam Proses Awal }\end{array}$ & & $\begin{array}{c}\text { Rp.1.836.972.629,42 } \\
-\end{array}$ \\
\hline Persediaan Produk Dalam Proses Akhir & & Rp.1836.972.619,42 \\
\hline $\begin{array}{l}\text { Harga Pokok Produksi } \\
\text { Persediaan Finish good awal }\end{array}$ & & $\begin{array}{c}\text { Rp.1836.972.619,42 } \\
-\end{array}$ \\
\hline $\begin{array}{l}\text { HPP tersedia Untuk Dijual } \\
\text { Persediaan Untuk Produk Akhir }\end{array}$ & & $\begin{array}{c}\text { Rp.1836.972.619,42 } \\
-\end{array}$ \\
\hline Harga Pokok Penjualan & & Rp.1836.972.619,42 \\
\hline
\end{tabular}

Berdasarkan hasil observasi mengenai penerapan metode full costing sebagai dasar perhitungan harga pokok produksi dalam menentukan harga jual produk botol plastik pada industri manufaktur yang telah dikemukakan di atas, maka dapat dilihat bahwa harga pokok produksi botol plastik dengan metode full costing sebesar Rp 1.889.682.559. Harga pokok 
produksi per satu botol plastik dengan metode full costing sebesar Rp 122.00. Industri manufaktur menjual 15.000.000 unit botol plastik. Dengan rincian sebagai berikut:

Tabel 4 Harga Jual Per Botol

\begin{tabular}{lll}
\hline \multicolumn{3}{c}{ Harga Pokok Produksi } \\
\hline 15.000 .000 & & \\
Unit & Rp.1.836.322.619,42 & Rp.122/botol \\
Pengambilan Keuntungan 22\% & Rp.26,53/botol \\
& Total & Rp.148,84 \\
& Harga Jual/botol & Rp.150 \\
\hline
\end{tabular}

Sumber: Data diolah

Dalam kasus Harga Pokok Produksi dan Harga Jual yang terdapat pada tabel 4 dalam menentukan harga jual sudah benar, dikarenakan sudah sesuai dengan target laba yang diinginkan yaitu sebesar 22\% sehingga harga botol plastik menjadi Rp 150 per unit botol. Dari harga jual sebesar Rp. 150/botol industri memutar modal dan memperoleh keuntungannya. Harga jual Rp 150 adalah harga jual hasil pembulatan dari Rp 148,84 dikarenakan bertujuan menutup biaya-biaya yang tak terduga yang muncul seperti kerusakan mesin, terjadinya kerusakan pada material handling, terjadi kerusakan gedung yang diakibatkan faktor lingkungan dan sebagainya. Sebenarnya, biaya-biaya tak terduga tersebut masuk ke dalam overhead pabrik dalam perhitungan Harga Pokok Produksi dikarenakan perusahaan tidak ingin membuat harga botol menjadi lebih mahal, supaya dapat bersaing dengan perusahaan lain yang memproduksi barang sejenis. Harga jual yang ditetapkan merupakan harga yang wajar dan mengikuti harga pasar.

\section{PENUTUP}

Berdasarkan hasil pengolahan data dan analisis yang telah dilakukan maka dapat disimpulkan bahwa:

1. Harga Pokok Penjualan dengan menggunakan metode full costing adalah Rp 1.889.682.559.

2. Dengan jumlah penjualan 15.000.000 unit diakumulasikan dengan harga jual per botolnya Rp 150 maka harga penjualan sebesar Rp 2.250.000.000. Keuntungan setelah pajak yang didapat oleh inustri manufaktur sebesar Rp 249.084.826,69 yang didapat dari penjualan botol plastik.

\section{REFERENSI}

Bustami, B (2013), Akuntansi Biaya (14 ed). Jakarta: Mitra Wacana Media

Firdaus dan Warsilah. 2009. Akuntansi Biaya, Edisi Tiga, Salemba Empat, Jakarta. Hansen dan Mowen. 2012. Akuntansi Manajemen. Salemba Empat, Jakarta.

Hansen,Don R dan Maryanne M. Mowen. 2009, Akuntansi Manajerial. Salemba Empat: Jakarta. 
Mulyadi, 2005. Akuntansi Biaya. Edisi ke-5. Yogyakarta: Akademi Manajemen Perusahaan YKPN.

Mulyadi. 2012. Akuntansi Biaya, Edisi Kelima, Cetakan Kesebelas, UPP STIM YKPN, Yogyakarta.

Stanton, William J. 1993. Prinsip Pemasaran. Edisi ke Tujuh. Jilid Ke-1. Jakarta: Erlangga.

Krismiaji,Aryani Y. Ani, 2011. Akuntansi Biaya. Edisi 11. Salemba Empat, Jakarta.

Slat, Andre Henri. 2013. Analisis Harga Pokok Produk Dengan Metode Full Costing Dan Penentuan Hrga Jual. Jurnal EMBA, Vol. 1, No. 3, ISSN 2303-1174: H. 110-11

Witjaksono, Armanto. 2006. Akuntansi Biaya Yogyakarta:GrahaIlmu 